\title{
Studi In silico Potensi aktivitas 10-shogaol dalam Jahe (Zingiber officinale) terhadap gen ACE
}

\section{In silico Study: Potential activity of 10-shogaol in Zingiber officinale through ACE Gene}

\author{
Mansur S $\stackrel{1 \times}{,}$ Yohanes Bare ${ }^{1}$, Maria Helvina², Aprianus Pani Pili ${ }^{1}$, Gabriella \\ Chandrakirana Krisnamurti ${ }^{3}$
${ }^{1}$ Program Studi Pendidikan Biologi, Fakultas Keguruan dan Ilmu Pendidikan, Universitas Nusa Nipa, Maumere, 86113,Indonesia
2 Program Studi Pendidikan Guru Sekolah Dasar, Fakultas Keguruan dan Ilmu Pendidikan, Universitas Nusa Nipa, Maumere, 86113,Indonesia
${ }^{3}$ Biotechnology Program, School of Bioresources and Technology, King Mongkut's University of Technology Thonburi, 10150 Bang Khun Thian, Bangkok, Thailand

Email: yuliantifitriani07@gmail.com

\begin{abstract}
Abstrak. Peningkatan tekanan darah tinggi (hipertensi) mengakibatkan terpicunya berbagai macam penyakit kronis serta komplikasinya. Salah satu activator dalam kondisi tekanan darah tinggi adalah aktivitas Angiotensin converting enzyme (ACE). ACE berperan dalam mengatur sistem renin-angiotensin. Penurunan hipertensi perlu untuk menekan aktivitas ACE. Tujuan dari penelitian ini adalah untuk menganalisis potensi 10-shogaol terhadap ACE. Metode yang digunakan adalah studi in silico. Protein model ACE (ID: 3bkk) didapatkan dari database Protein data Bank (PDB) sedangkan 10-shogaol (CID: 6442612) didapat dari database PubChem. Docking menggunakan Hex 8.0.0 sedangkan visualisasi dan analisis menggunakan Discovery Studio. Hasil Penelitian menunjukan bahwa senyawa 10-shogaol memiliki potensi sebagai inhibitor gen ACE dibuktikan 2 residu asam amino yang berikatan dengan ligan. Ikatan tersebut berupa ikatan hidropobik yang meningkatkan kekuatan tersebut dengan besar energi $-291.3 \mathrm{cal} / \mathrm{mol}$.
\end{abstract}

Kata Kunci: 10-Shogaol; Ace; In silico; Inhibitor; Jahe

\section{Pendahuluan}

tinggi (hipertensi) mengakibatkan terpicunya berbagai macam penyakit kronis, diantaranya penyakit jantung, stroke, penyakit jantung coroner serta, komplikasinya meliputi penyakit pembuluh darah perifer, gagal jantung, gangguan pada ginjal, perdarahan yang etrjadi pada retinal, serta mengakibatkan penglihatan gangguan [1], [2]. Data menunjukan bahwa tekanan darah tinggi sebagai salah satu penyakit berbahaya, karena lebih dari 7,5 juta kematian atau $12,8 \%$ dari total semua kematian tahunan di seluruh dunia [2]. Kondisi hipertensi tidak terlepas dengan kondisi inflamasi, pada saat yang bersamaan terjadi perbedaan 
jumlah komposisi protein yang berfungsi hal ini meningkatkan tingkat hipertensi pada manusia [3]. Salah satu mediator dalam proses tekanan darah tinggi adalah aktivitas Angiotensin converting enzyme (ACE). ACE berperan dalam mengatur sistem reninangiotensin, yaitu mengubah angiotensin-I (ATI) menjadi angiotensin-II (ATII). Gen ini juga memiliki efek hidrolisis dan menonaktifkan protein vasodilator [4].

Dalam menurunkan prevelensi hipertensi, perlu dilakukan system terapi terhadap gen yang memiliki

\section{Metode}

\section{Persiapan Ligan dan Protein}

Protein model ACE (ID: 3bkk) didapatkan dari database Protein data Bank (PDB). Sebelum docking dilakukan ACE harus disterilisasi terlebih dahulu dengan menggunakan BioVia Discovery Studio. Setelah ACE dibersihkan dari molekul air dan. Kemudian 10-shogaol (CID: 6442612) didapat dari database PubChem. 10shogaol didapatkan dengan cara mengkonstruksi ulang bentuk tiga dimensi menggunakan Canonical SMILES yang tersedia di database PubChem. Konstruksi ini dilakukan bertujuan agar 10-shogaol yang

\section{Hasil dan Pembahasan}

Pada interaksi 10-shogaol dan ACE tidak ditemukan ikatan hidrogen yang terbentuk, akan tetapi ditemukan aktivitas dengan cara menghambat kinerjanya. Penghambatan ini dilakukan dengan mencoba mengkaji bioaktif sumber daya alam yang digunakan sebagai inhibitor ACE. Rimpang jahe memiliki komponen polifenol terbesar, salah satunya adalah 10-shogaol [5], [6]. Senyawa komponen polifenol diprediksi memiki sifat farmakologi akan tetapi belum ada informasi rinci mengenai efek dan bagaimana cara kerja senyawa 10-shogaol terhadap gen ACE. Tujuan dari penelitian ini adalah untuk menganasisi potensi 10shogaol terhadap ACE. Metode yang digunakan adalah studi in silico.

digunakan masih dalam keadaan netral dan belum bernteraksi dengan molekul apapun [7].

\section{Docking ACE dan 10-shogaol}

Docking ACE dan 10-shogaol yang terkandung dalam dalam jahe dianalisis dengan menggunakan Hex 8.0.0. Perhitungan energi dilakukan dengan masing-masing server tersebut. Visualisasi 3D hasil docking tersebut dilihat dengan menggunakan program Discovery Studio dan PyMol untuk menganalisis residu asam amino, energi yang berikatan, gaya van der waals, dan ikatan hydrogen yang terbentuk [8], [9].

ikatan tipe Pi-Sigma pada residu asam amino TRP357, hydrophobic tape PiAlkyl pada residu asam amino TYR360. 


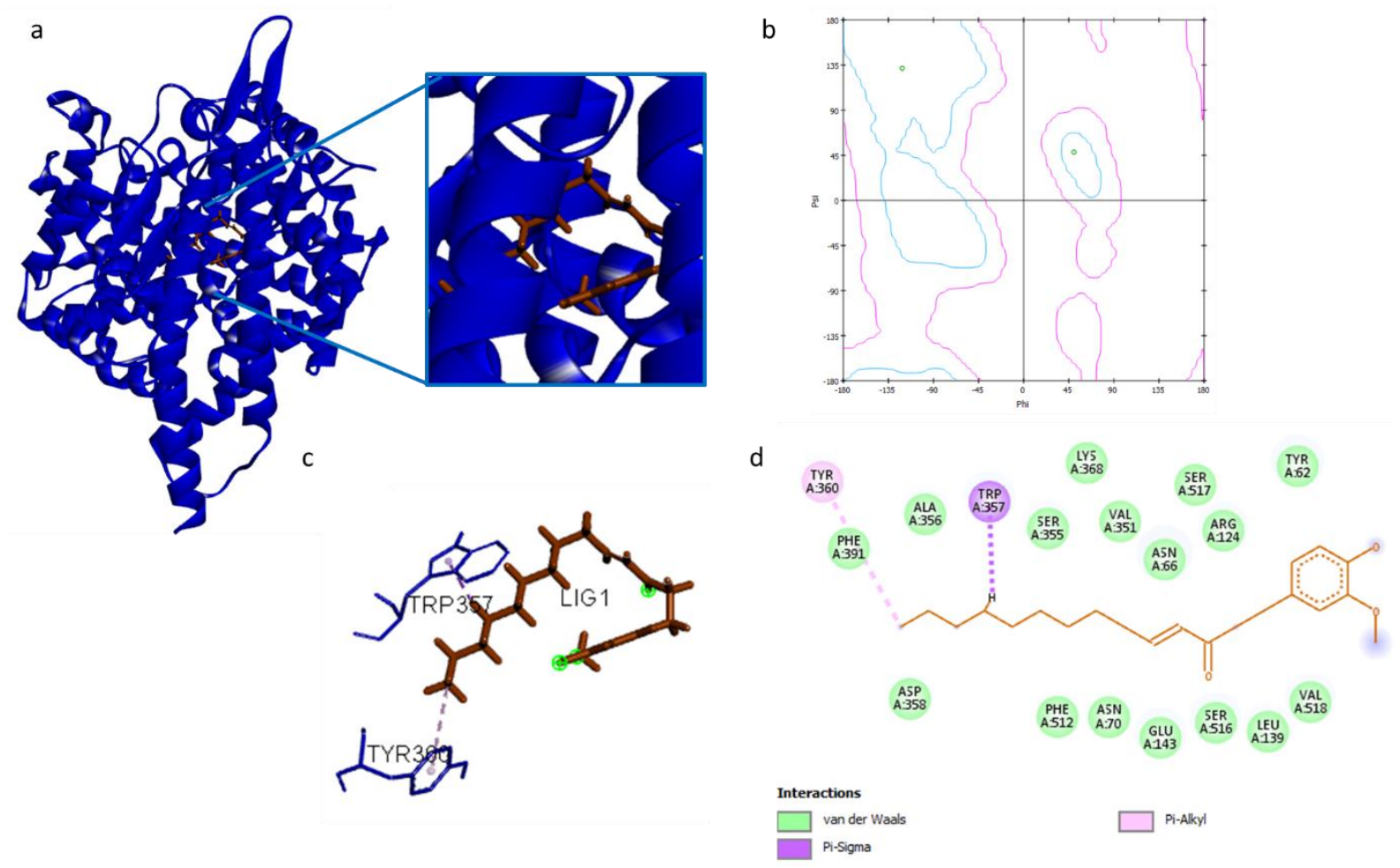

Gambar 1. Kompleks 10-Shogaol-ACE, a. daerah ikatan 10-Shogaol-ACE, b. Ramachandran plot kompleks 10-Shogaol-ACE, c. 3D sisi aktif 10-Shogaol-ACE, d. 2D sisi aktif 10-ShogaolACE.

Sebagai pendukung dari ikatan tersebut ditemukan residu asam amino yang yang masuk dalam golongan gaya Van der Waals yaitu PHE391, ALA356, SER355, LYS368, VAL351, ASN66, SER517, ARG124, TYR62, ASP358, PHE512, ASN70, GLU143, SER516, LEU139, VAL5128. Terdapat dua residu asam amino yang ditemukan berinteraksi dengan 10shogaol yaitu residu asam amino TRP357 dan TYR360, ikatan keduanya menghasilakan energi ikatan sebesar $291.3 \mathrm{cal} / \mathrm{mol}$. Ikatan dengan jumlah yang paling kecil akan memberikan ikatan yang maksimal pada ligan dan protein [10]. 


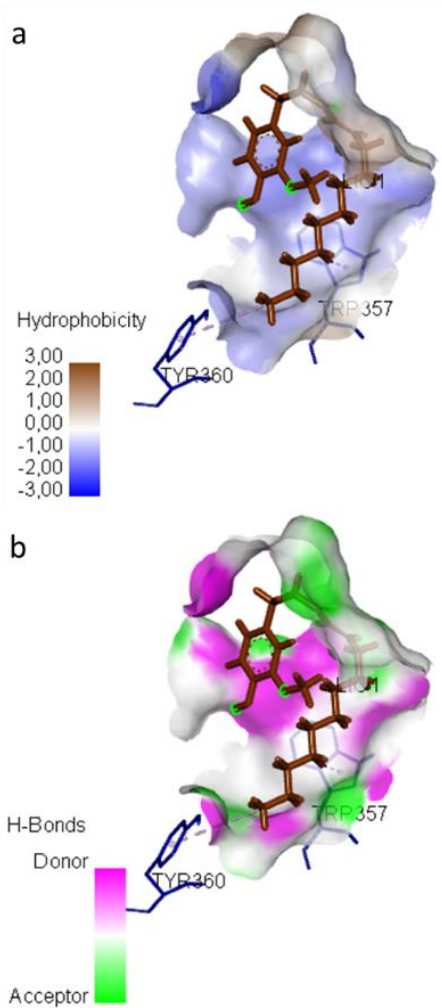

C

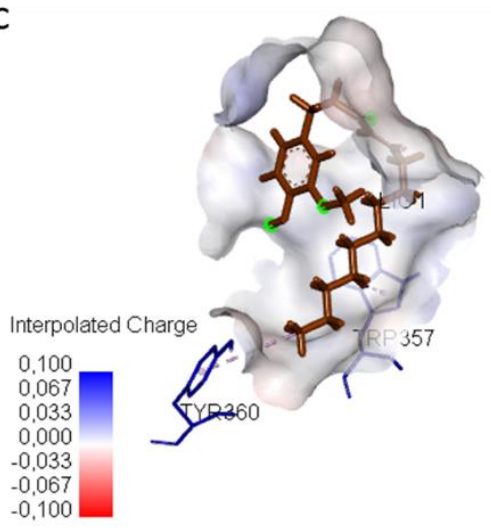

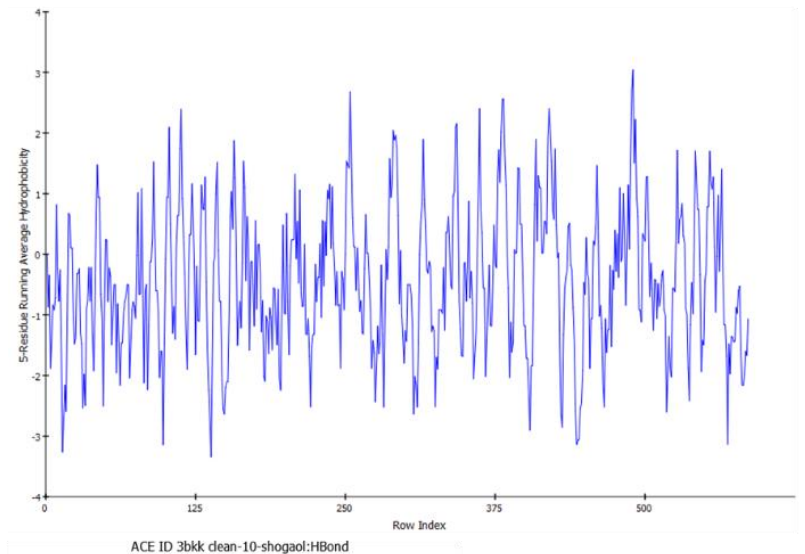

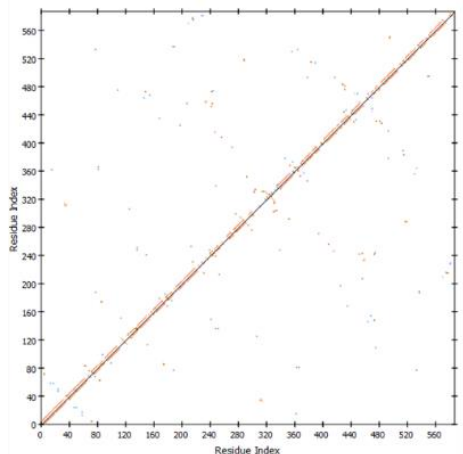

d

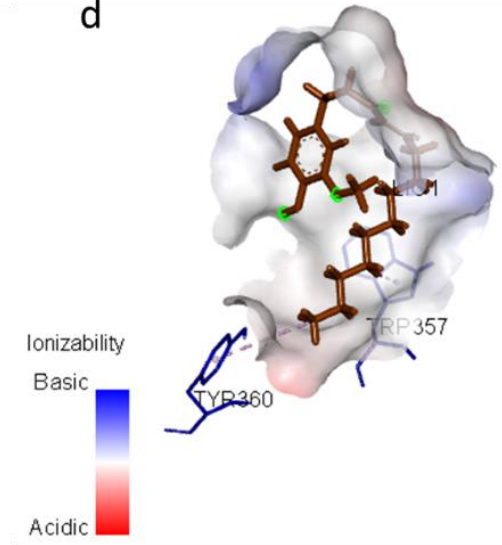

e

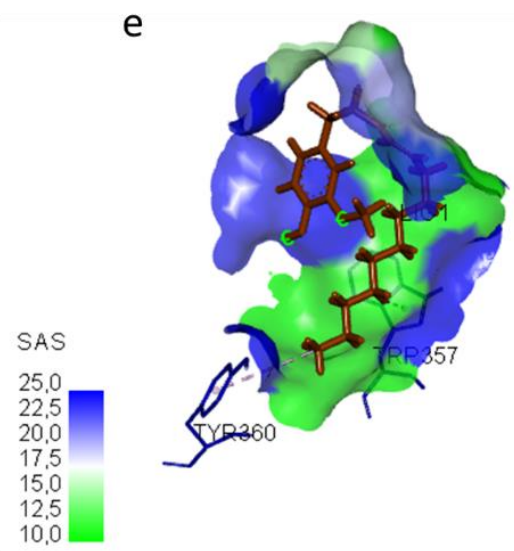

Gambar 2. Fisikokimia kompleks 10-Shogaol-ACE, a. hidrofobisitas dan plot hydrofobisitas 10-ShogaolACE, b. hydrogen bond dan plot ikatan hydrogen 10-Shogaol-ACE, c. muatan sisi aktif 10Shogaol-ACE, d. ionisasi dan e. solvent accessible surface.

Level hidrofobisitas 10-shogaol dan ACE menunjukan tingkat yang sangat rendah karena sebagian besar permukaan ligan telihat berwarna biru muda menuju ke biru tua (gambar 2a), sedangkan residu asam amino menunjukan sebagai donor dan acceptor terhadap protein model ACE (gambar 2b). Interaksi yang terbentuk memperlihatkan keadaan netral dengan nilai 0 karena sebagian besar permukaan tertutupi oleh warna abuabu yang mengindikasikan nilai 0 (gambar 2c, 2d). Nilai solvent accessible surface (SAS) pada permukaan 10-shogaol menunjukan nilai yang sangat tinggi hal tersebut dikarenakan oleh hampir sebagian besar permukaan yang tertutupi oleh warna biru (gambar 2e). 
Tabel 1. Interaksi antara 10-Shogaol dengan Angiotensin converting enzyme I (ACE)

\begin{tabular}{|c|c|c|c|c|c|c|c|c|c|}
\hline Interactions & $\begin{array}{l}\text { Energy } \\
\text { (cal/mol) }\end{array}$ & Name & Distance & Category & Types & Donor & $\begin{array}{c}\text { From } \\
\text { Chemistry }\end{array}$ & Acceptor & $\begin{array}{c}\text { To } \\
\text { Chemistry }\end{array}$ \\
\hline \multirow{2}{*}{$\begin{array}{l}\text { ACE-10- } \\
\text { Shogaol }\end{array}$} & \multirow{2}{*}{-291.3} & $\begin{array}{l}\text { :LIG1:H - } \\
\text { A:TRP357 }\end{array}$ & 2,40895 & $\begin{array}{l}\text { Hydropho- } \\
\text { bic }\end{array}$ & Pi-Sigma & :LIG1:H & $\mathrm{C}-\mathrm{H}$ & A:TRP357 & Pi-Orbitals \\
\hline & & $\begin{array}{l}\text { A:TYR360 } \\
\text { - :LIG1:C }\end{array}$ & 5,11662 & $\begin{array}{l}\text { Hydropho- } \\
\text { bic }\end{array}$ & Pi-Alkyl & A:TYR360 & Pi-Orbitals & :LIG1:C & Alkyl \\
\hline
\end{tabular}

Teknik analisis in silico yang dilakukan telah berhasil menunjukkan efek positif, karena senyawa 10-shogaol berperan dalam menghambat pembentukan hipertensi dalam proses penghambatan aktivitas enzim ACE. Penghambatan ini merupakan aktivitas biologis sebagai bukti penghambat ACE. Dua residu asam amino menunjukkan interaksi yang berinterasksi dengan 10-shogaol. Interaksi 10-shogaol dan ACE tidak ditemukan ikatan hidrogen yang terbentuk, akan tetapi ditemukan ikatan tipe Pi-Sigma pada residu asam amino TRP357, hydrophobic tape Pi-Alkyl pada residu asam amino TYR360. Beragam ikatan yang mebentuk interaksi antara ligan dan protein akan mendukung sereta meinngkatkan energy ikatan yang terbentuk [11]-[15].

Kombinasi sisi aktif asam amino dengan 2 residu asam amino berpengaruh pada konversi ACE.
Penghambat ACE yang diturunkan dari nutrisi telah dipelajari secara ekstensif dan memiliki efek biologis yang berbeda [16]. Adanya ikatan gaya hidrofobik serta gaya van der Waals berperan positif dalam memperkuat ikatan tersebut. Selain itu, ikatan tersebut juga memberikan kestabilan antara ligan dan protein. Energi binding ligan-protein 10-shogaol adalah sebesar $-291.3 \mathrm{cal} / \mathrm{mol}$. Informasi awal menunjukkan bahwa mengonsumsi makanan yang kaya senyawa flavonoid dapat memediasi penurunan tekanan darah, yang memungkinkan untuk mengeksplorasi nutrisi dengan kandungan flavonoid yang tinggi, yang dapat digunakan sebagai penghambat ACE [17]. Konversi dan regulasi sistem renin-angiotensin terhambat karena sisi aktifnya ditutupi oleh 10-shogaol, namun efek selanjutnya adalah proses konversi angiotensin-I menjadi angiotensin-II juga terhambat.

\section{Simpulan}

Berdasarkah hasil penelitian dan diskusi disimpulkan bahwa senyawa 10shogaol memiliki potensi sebagai inhibitor gen ACE dibuktikan 2 residu asam amino yang berikatan dengan ligan. Ikatan tersebut berupa ikatan hidropobik yang meningkatkan kekuatan tersebut dengan besar energi $-291.3 \mathrm{cal} / \mathrm{mol}$.

\section{Acknowledgements}

Ucapan terima kasih kami ucapkan kepada Yayasan Pendidikan Tinggi Nusa Nipa dan Universitas Nusa Nipa sebagai pendana pada penelitian melalui program Hibah Penelitian Yayasan Pendidikan Tinggi Nusa Nipa. Kepada saudari Dewi Ratih Tirto Sari yang membantu dalam penelitian ini. 


\section{Daftar Pustaka}

[1] S. Singh, R. Shankar, and G. P. Singh, "Prevalence and Associated Risk Factors of Hypertension: A Cross-Sectional Study in Urban Varanasi," Int. J. Hypertens., vol. 2017, pp. 1-10, 2017, doi: 10.1155/2017/5491838.

[2] World Helath Organization, Global status report on noncommunicable diseases 2010. Italy: World Helath Organization, 2011.

[3] Y. Bare, A. Marhendra, T. Sasase, and F. Fatchiyah, "Differential Expression of IL10 Gene and Protein in Target Tissues of Rattus Norvegicus Strain Wistar Model Type 2 Diabetes Mellitus (T2DM)," Acta Inform. Medica, vol. 26, no. 2, pp. 87-92, 2018, doi: 10.5455/aim.2018.26.87-92.

[4] W. Ouwerkerk et al., "Determinants and clinical outcome of uptitration of ACEinhibitors and beta-blockers in patients with heart failure: a prospective European study," Eur. Heart J., vol. 38, no. 24, pp. 1883-1890, Jun. 2017, doi: 10.1093/eurheartj/ehx026.

[5] Q.-Q. Mao et al., "Bioactive Compounds and Bioactivities of Ginger (Zingiber officinale Roscoe)," Foods, vol. 8, no. 6, p. 185, May 2019, doi: 10.3390/foods8060185.

[6] A. Ghasemzadeh, H. Jaafar, A. Baghdadi, and A. Tayebi-Meigooni, "Formation of 6-, 8- and 10-Shogaol in Ginger through Application of Different Drying Methods: Altered Antioxidant and Antimicrobial Activity," Molecules, vol. 23, no. 7, p. 1646, Jul. 2018, doi: 10.3390/molecules23071646.

[7] H. N. Meidinna and Fatchiyah, "The Potential Role of Rosmarinic Acid and Sinensetin as a- Amylase Inhibitor: In Silico Study," J. Pure Appl. Chem. Res., vol. 8, no. 1, pp. 73-79, Apr. 2019, doi: 10.21776/ub.jpacr.2019.008.001.460.

[8] Y. Bare, M. S, S. H. J. Putra, M. R. W. G. L, and D. R. T. Sari, "In-silico Approach for The Prediction of Chlorogenic Acid as PPAR-y Activator," Biota, vol. 13, no. 1, Jun. 2020, doi: 10.20414/jb.v13i1.197.

[9] D. Sari, J. Cairns, A. Safitri, and F. Fatchiyah, "Virtual Prediction of the Delphinidin3-O-glucoside and Peonidin-3-O-glucoside as Anti-inflammatory of TNF- and \#945; Signaling," Acta Inform. Medica, vol. 27, no. 3, p. 152, 2019, doi: 10.5455/aim.2019.27.152-157.

[10] S. S. N. D. Tiring, Y. Bare, A. Maulidi, M. S, and F. A. D. Nugraha, "Studi In Silico: Prediksi Potensi 6-shogaol dalam Zingiber officinale sebagai Inhibitor JNK," AlKim., vol. 7, no. 2, pp. 147-153, 2019, doi: 10.24252/al-kimia.v7i2.10638.

[11] Y. Bare, A. D. Kuki, A. H. Rophi, and G. Candrakirana, "Prediksi Asam Kuinat Sebagai Anti-Inflamasi Terhadap COX-2 Secara Virtual Virtual Prediction of Quinic Acid As Anti-Inflammation of COX-2," Biota J. IImu-IImu Hayati, vol. 4, no. 3, pp. 124-129, 2019, doi: https://doi.org/10.24002/biota.v4i3.2516.

[12] Y. Bare, D. R. T. Sari, Y. T. Rachmad, G. C. Krisnamurti, and A. Elizabeth, "In Silico Insight the Prediction of Chlorogenic Acid in Coffee through Cyclooxygenase-2 (COX2) Interaction," Biog. J. IIm. Biol., vol. 7, no. 2, pp. 100-105, Dec. 2019, doi: 10.24252/bio.v7i2.9847.

[13] K. H. Choi, L. Kremer, G. S. Besra, and C. O. Rock, "Identification and substrate specificity of $\beta$-Ketoacyl (Acyl carrier protein) synthase III (mtFabH) from mycobacterium tuberculosis," J. Biol. Chem., vol. 275, no. 36, pp. 28201-28207, 2000, doi: 10.1074/jbc.M003241200. 
[14] B. Jia, Y. M. Ma, B. Liu, P. Chen, Y. Hu, and R. Zhang, "Synthesis, Antimicrobial Activity, Structure-Activity Relationship, and Molecular Docking Studies of Indole Diketopiperazine Alkaloids," Front. Chem., vol. 7, no. November, pp. 1-13, 2019, doi: 10.3389/fchem.2019.00837.

[15] D. R. T. Sari and Y. Bare, "Physicochemical properties and biological activity of bioactive compound in Pepper nigrum: In silico study," vol. 1, no. 2, p. 6, 2020.

[16] K. Erdmann, B. W. Y. Cheung, and H. Schröder, "The possible roles of foodderived bioactive peptides in reducing the risk of cardiovascular disease," J. Nutr. Biochem., vol. 19, no. 10, pp. 643-654, Oct. 2008, doi: 10.1016/j.jnutbio.2007.11.010.

[17] L. Actis-Goretta, J. I. Ottaviani, and C. G. Fraga, "Inhibition of Angiotensin Converting Enzyme Activity by Flavanol-Rich Foods," J. Agric. Food Chem., vol. 54, no. 1, pp. 229-234, Jan. 2006, doi: 10.1021/jf052263o. 